\title{
Andreae Vesalii: The Temporomandibular Joint
}

\author{
Andrés Vesalio: La Articulación Témporomandibular \\ "Henrique Ayres de Vasconcellos \& ${ }^{* *}$ Pedro Henrique Barros de Vasconcellos
}

VASCONCELLOS, H. A. \& VASCONCELLOS B. P. H. Andreae Vesalii: The temporomandicular joint. Int. J. Morphol., 24(1):105$109,2006$.

SUMMARY: The Temporomandibular Joint (TMJ) has been studied for many years since the finding of mummies and fossils. In Egypt of the pharaos, papyrus from the year 3000 B.C. remark the care in which a luxation of the TMJ should be undertaken. In India, at the beggining of the Christian age, in Hipocrates' Greece and in Pergamo of Galenus the TMJ has also been the focus of several studies. But it was Vesalius (Andreae Vesalli), with his particular teaching methodology and publication of his masterpiece De Humani Corporis Fabrica, who showed the way to study Human Anatomy as it is done today. The description of the face bones, of the articular disc and the muscles used for chewing are all a contribution from Vesalius to the anatomic-functional study of TMJ.

KEY WORDS: Andreae Vesalii; TMJ; Temporomandibular Joint; History of Anatomy.

\section{INTRODUCTION}

The Temporomandibular Joint (TMJ) is being studied since remote ages. The founding of human fossils and mummies, from several backgrounds and ages, has much contributed to the researches, since the mandible and skull were found intact in most of the cases.

"And it will be said, this man has a dislocated mandible. It is a disease which I can cure"- this extract, taken from observation 25 from an egipcian papyrus, deals with the art of examining, diagnosing and curing these dislocations. At first dated during the year 1650 b.C., it was later proved that it belonged to an older dynasty - from 3000 b.C.

Medical texts from the first 6 centuries of the Christian age in India, called Samhitâ, pinpoint the ethiological factor for causing the luxation of the TMJ "The Wind" - due to speaking loudly, chewing hard foods or shouting. In the chapter named About teeth diseases the treatment for luxation is described.

Through texts atributed to Hipócrates (century IV a.C.), the Greeks, known as Corpus Hippocraticum, enphasize the separation of belief in gods and miracles from the birth of a rational medicine. Fractures and luxation are described with details in the "Book of the Joint" (Lemos, 1995).

\footnotetext{
${ }^{*}$ MD. Ph.D. Anatomy Department, FMP-RJ and IB/UERJ, Brazil

** MD. Anatomy Department IB/UERJ, Brazil.
}

Claudius Galenus (131-201), from Pérgamon, was considered the first team doctor and father of Kinesiology. Galenus considered the jaw to be divided in two parts, a thought that was later adopted by many anatomists who followed him.

In 1543 the book - De Humani Corporis Fabrica Líber Septem - written by Andrae Vesalli - answering many questions about the human body, which starts to be studied more profoundly and precisely (Singer, 1996; Vasconcellos \& Vasconcellos, 2004).

The main objective of this current study is to research and analyse how Vesalius' work, especially Fabrica, contributed to the acknowledgment of anatomy - either descriptive and functional - of the TMJ.

Andreae Vesalii - a life dedicated to the practice of anatomy: Andreas van Wesele was born in Bruxels, Belgium, in $31^{\text {st }}$ December in 1514. Since an early age he showed interest in Anatomy, being seen dissecting animal bodies. He latinized his name, turning it into Andreae Vesalli (Andreas Vesalius, André Vesálio), how he is known. Andreae married to Anne van Hamme in 1544, and from this union a daughter was born a year later-Anne. He studied in Louvain, 
Paris and Pádua graduating in Medicine in the year of 1537, being nominated Chief of the Surgery and Anatomy Department in Padua University, soon after receiving his diploma. The classes with dissections of bodies and publications made Vesalius famous and admired. However, the controversy aroused by the new knowledge introduced by him, produced enemies since they stood against the galenism, which was accepted and practiced in the scientific circle of the time.

The book "De Humani Corporis Fabrica Liber Septem", published in Basle in 1543, is the main work of the Modern Human Anatomy. Composed of 7 books (1 - Bones and Joints ; 2 - Muscles; 3 Circulatory System; 4 - Nervous System; 5 - Abdomen Visceras; 6 - Heart and Lungs; 7 - Brain), the Fabrica brought several explanations to the anatomic studies and research. The illustrations are its main features, precisely showing the many organic systems, which characterize the concept about the importance of the acknowledgment of the anatomy as the foundation of the medical art (O'Rahily, 1993; Singer; Friedman \& Friedland, 2000; Bezerra, 2002; Vasconcellos \& Vasconcellos).

\section{Andreae Vesalii and the temporomandibular joint.}

The scientific publications dated before Vesalius were unclear on the morphologic and functional descriptions of Human Anatomy. The studies were based on analogies, once they were carried out on animals, on which dissections and small experiences were made, all of which were possible and allowed at the time. The representations were simple schemes and did not demonstrate precisely what was necessary.

This situation has also occured with the study of the TMJ. The texts and pictures presented the subject through schemes, abdicating precise descriptions and the functional activity.

\section{TMJ - Bones and Joints - Fabrica.}

In the first book of the Fabrica (Bone and Joint), we see the skeleton of a dog's head with the pre-maxillary bone. In the same picture we are able to observe the bone structure of a human head, opposed to the dog's, without the mentioned bone. With that demonstration, Vesalius modifies one of Galeno's affirmation (Fig. 1).

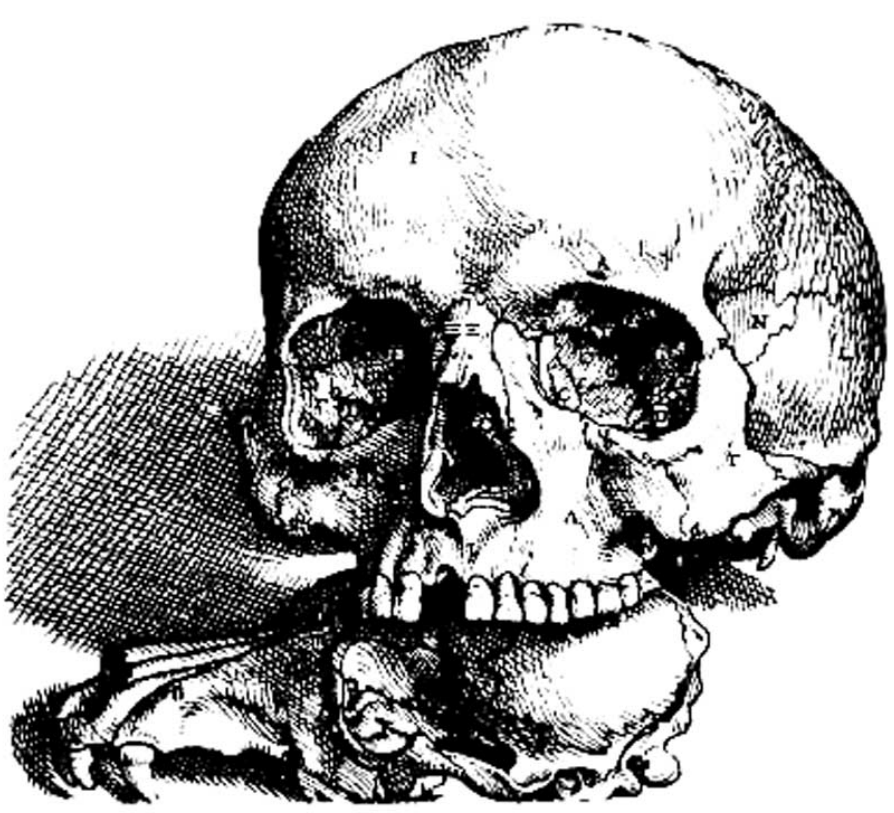

Fig. 1. The human skull is shown on the pre-maxillary observed in dogs (Singer, 1996; Saunders \& O`Malley, 2002; Vasconcellos \& Vasconcellos, 2004).

The mandible is represented in front and back views, with is morphology similar to how it is currently, not only because of the bone accidents but also due to the morphology, position and number of teeth (16). Vesalius was probably already in the direction of the recognition of the importance of dental occlusion, not only for chewing but also for the functioning of the TMJ.

In the same figure the articular disc can be seen, represented as a circle, put in front of the jaws. The distinction given to the disc, although without the morphologic precision of today, seems to emphasize the importance of its presence to the joint. This fact was news in the publications of the time, since more than the presentation of the structure, the author also seemed to want to give the disc an essential role in the functional relation of the mandible.

Therefore this aspect is the first information about an anatomic description, of the Temporomanibular Joint (Singer; Saunders; Vasconcellos \& Vasconcellos) (Fig. 2).

\section{TMJ - Muscles - Fabrica}

In book 2, the muscles are showed clearly and precisely, allowing the observation of its morphology, topography and stratigraphy. The drawings (in front and back views), show dissected body parts, in levels. 


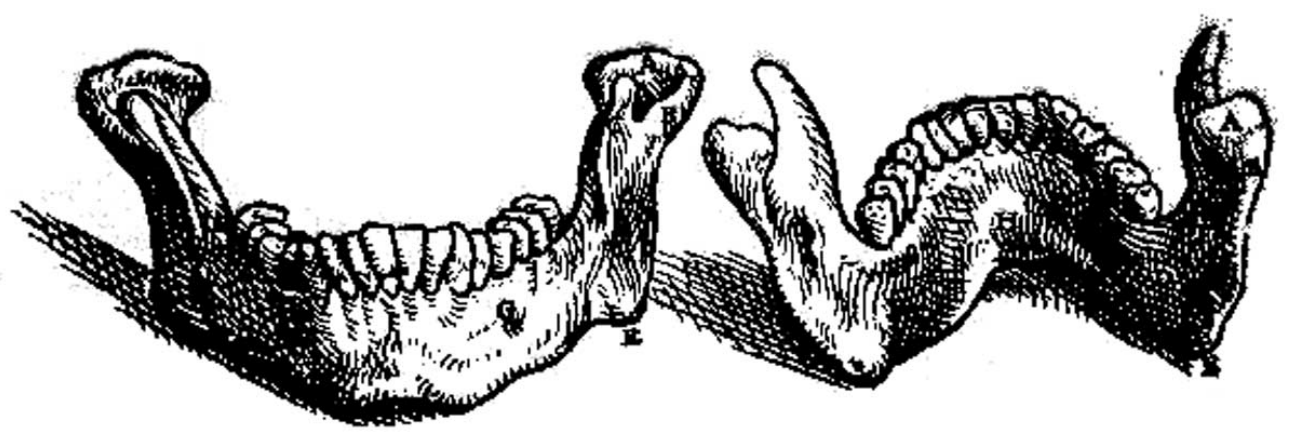

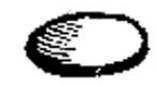

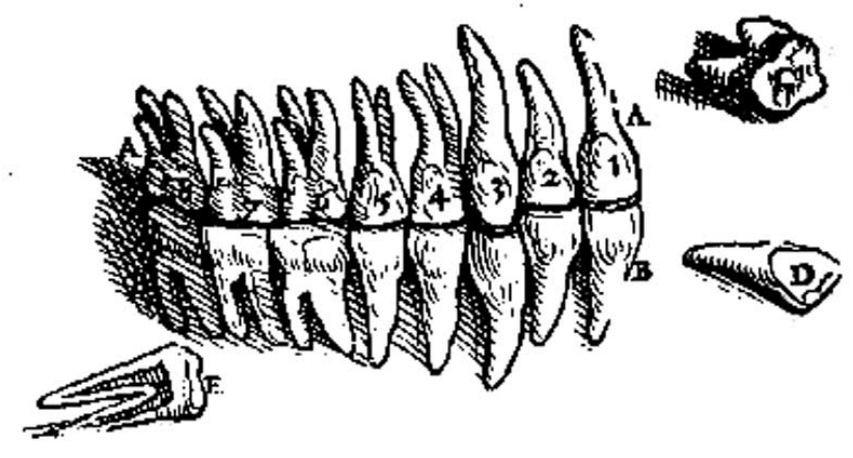

Fig. 2. Mandible as a single bone; the articular disk of temporomandibular joint (Saunders \& O’Malley, 2002; Vasconcellos \& Vasconcellos, 2002).

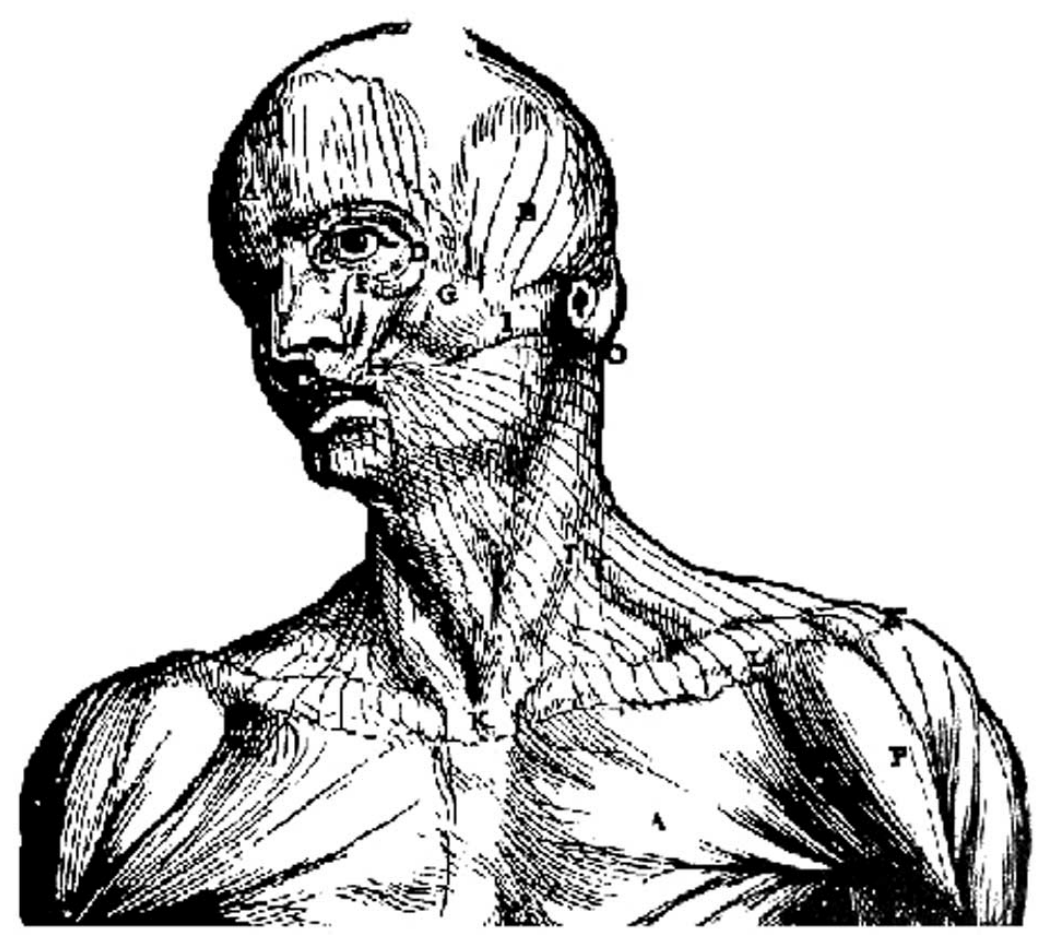

Fig. 3. Muscles of the face (Saunders \& O’Malley, 2002).
Another important aspect is the posture in which the bodies are presented in the drawings. They seem to be moving, performing muscular actions, since the body segments are not in the classic anatomic position. Through this Vesalius contributed once more with the demonstration of the muscles' dynamic, although in just one level, what was not emphasized in previous publications.

The facial expression muscles are seen in several drawings (Fig. 3). The dissection, in levels, shows that chewing muscles, like the masseter, temporal, internal pterygoid, suprahyoid and infra-hyoid. In the drawings which the mouth is opened, or those in which the mandible had been removed, the activity of those muscles can be observed. (Fig. 4). 


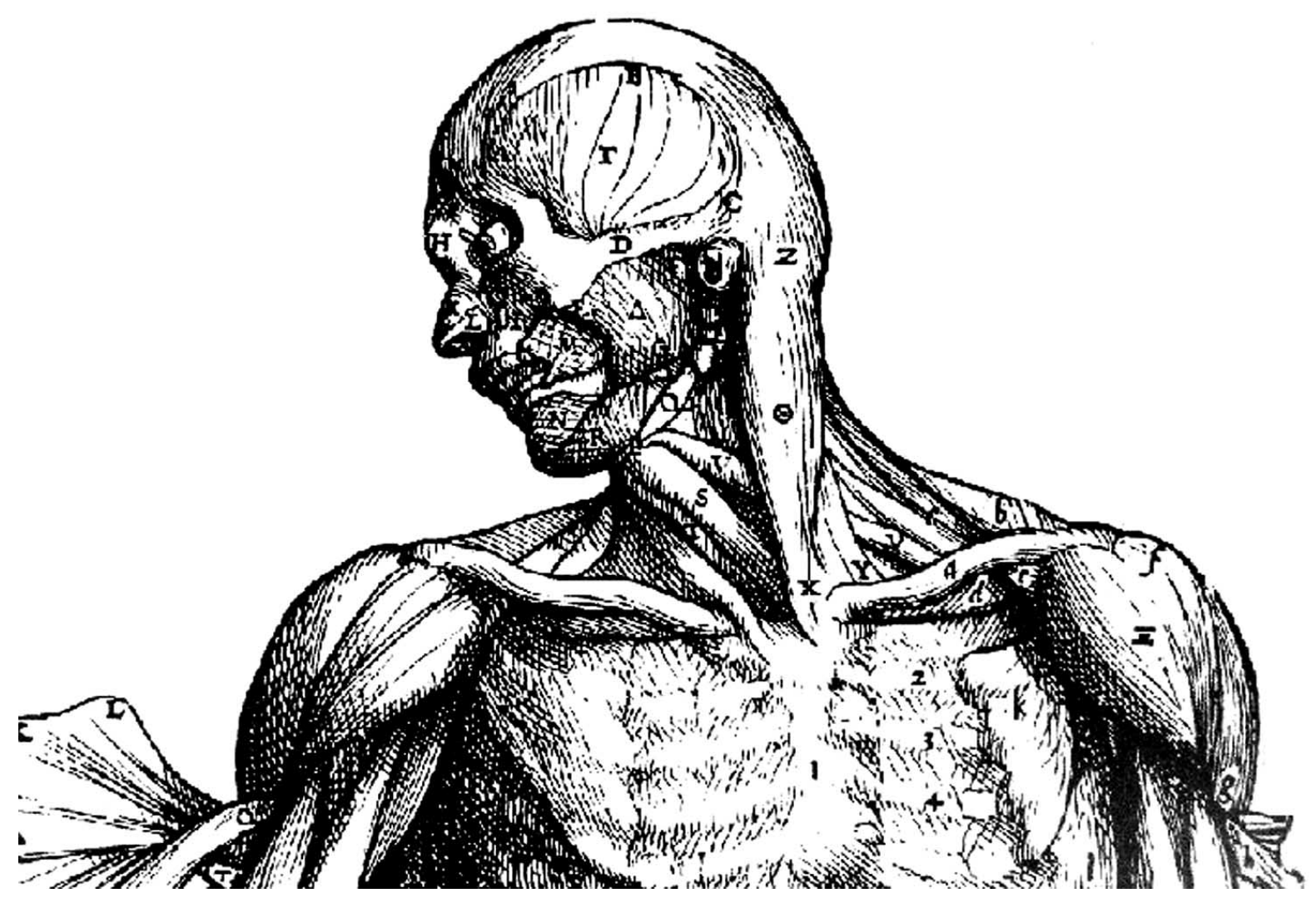

Fig. 4. Chewing muscles (Saunders \& O’Malley, 2002).

It is possible to observe with clarity the sterno-cleidomastoid and trapezius muscles, in front and back views, represented as if in action, confirmed by the position in which the head is drawn (Figs. 4 and 5).

We believe that the emphasized aspects show Vesalius' interest in trying to show the muscular dynamic, through the posture of the bodies. This fact enabled Vesalius' followers to study in depth the muscular kinesiology.

The same happens with the chewing dynamics, not only through the more precise bone representation, but also via the presence of the disc and the muscular function. Due to this the study of the TMJ was reinforced, allowing the current knowledge on the TMJ, either descriptive and functional (Singer; Saunders) (Figs. 3 and 4).

\section{Final Comments.}

To Singer, Vesalius was a very characteristic produce of his time, having as father the galenism, and mother, the beautiful creature - the new Art, during the flourishment of her youth. To the modern anatomist, Vesalius remains being the ideal of dedication and value of Human Anatomy, when we need to study, prepare and give a lesson, or even when we stand before a unknown corpse or our patient.

\section{ACKNOWLEDGMENTS}

We wish to tanks Gabriela de Barros Wirz Martins for the english manuscript and Brenda Tan Maia for the spanish revision.

VASCONCELLOS, H. A. \& VASCONCELLOS B. P. H. Andrés Vesalio: La articulación témporomandibular. Int. J. Morphol., 24(1):105109, 2006.

RESUMEN: La articulación témporomandibular (ATM) ha sido estudiada hace muchos años, desde el descubrimiento de fósiles y momias. En Egipto de los faraones, papiros del año $3000 \mathrm{aC}$ hacen referencia a los cuidados necesarios para el tratamiento de la luxación de la ATM. En India, al inicio de la era cristiana, en Grecia de Hipócrates y en Pérgamo de Galeno, también se estudió la ATM. Sin embargo, fue Andrés Vesalio, con su metodología de enseñanza y la publicación de su obra maestra, De Humani Corporis Fabrica, quien permitió que la Anatomía Humana se tornara conocida en la forma en que es estudiada hoy. La descripción de los huesos de la cara, del disco articular y de los músculos de la masticación, con sus acciones, constituyen la contribución de Vesalio para el estudio anátomo-funcional de la ATM.

PALABRAS CLAVE: Andrés Vesalio; ATM; Articulación Témporomandibular; Historia de la Anatomía. 


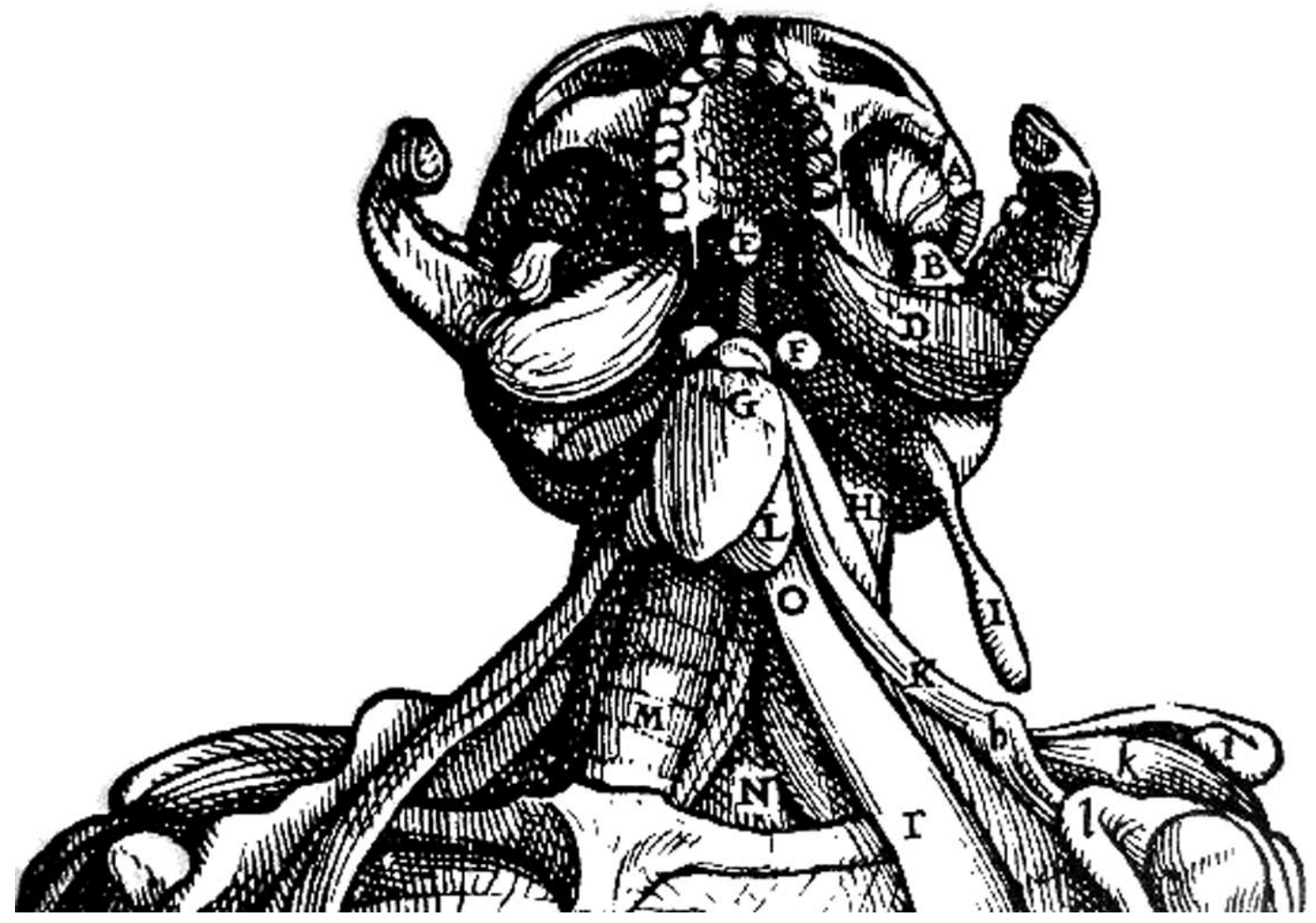

Fig. 5. Face without mandible (Saunders \& O’Malley, 2002).

\section{REFERENCES}

Bezerra, A. J. C. Admirável Mundo Médico: a Arte na História da Medicina. Brasília, Editora do Conselho Regional de Medicina do Distrito Federal, 2002.

Friedman, M \& Friedland, G. W. As Dez Maiores Descobertas da Medicina. São Paulo, Companhia das Letras, 2000.

Lemos, J. B. D. Resenha Histórica. In Tratamento da Disfunções Craniomandibulares - ATM. J. J. Barros \& Sigmar de Mello Rode (editores), São Paulo, Editora Santos, 1995.

Saunders, J. B. C. M. \& O’Malley, C. Andréas Vesalius de Bruxelas. Campinas, Ateliê Editorial - Edital UnicampImprensa Oficial, SP, 2002.

Singer, C. Uma breve História da Anatomia e Fisiologia desde os Gregos até Harvey. Campinas, Editora Unicamp, 1996.

Vasconcellos, H. A. \& Vasconcellos, P. H. B . Andreae Vesalii: the bone and muscles. Int. J. Morphol., 22(1):5-8, 2004.
Correspondence to:

Prof. Dr. Henrique Ayres de Vasconcellos

Caixa Postal 46523

CEP: $20552-970$

Rio de Janeiro - $R$

BRAZIL

E-mail:havasc@uerj.6r philoto@gmail.com

Received: 11-11-2005

Accepted: 05-01-2006 